\title{
DAMAGE TO RAILWAY TRACK
}

\author{
*W. J. H. Duckworth
}

\section{Introduction}

The Inangahua earthquake brought to a standstill all train operations on the lest Coast. The first concern was to inspect the track and bridges to determine whether they were safe for a resumption of train services.

The Ross, Rewanul and Rapahoe lines experienced little damage and services were resumed without much delay. The Midland Line had suffer ed some damage especially at bridge approaches where the formation settled. Also on the Midland at Kaimata (60 miles from Inangahua) a saturated embankment slumped and it was 16 hours before trains were running again.

The area worst effected was concentrated in a 20 mile radius of Inangahua. This was between Cronadun and Tiroroa on the StillwaterVestport Line and Waimangaroa and Nikau on the Mokihinui Line. The latter area was soon in operation but subject to severe operating restrictions. The damage in the former area was repaired sufficiently for traffic to be resumed on 17 th June and the mopping up was completed by 24 th september.

\section{Damage estimation-Cronadun to Tiroroa}

The initial difficulty was in obtaining a clear picture of the location, type and extent of damage. To add to the problem was the non existence of communications in the area - the Department's own telephone system had been badly damaged by slips and was not restored before the end of the emergency. To set about assessing the damage, inspections were made by foot, trolley, farm tractor, jet boat, helicopter and chartered aircraft. This was a slow job and it was not till 29 th May before the full extent of the damage was known.

\section{Description of damiage}

Besides the bridge damage described in the paper "Damage to Railway bridges and other structures" by J. P. Hollings and J. B. Hilson the trace suffered danage in the following ways:

Firstly where the track was in cuttings or sidlings the sides gave way and slip material including trees and boulders 100 tons or more in size covered the track. Where this happened the track was in some places severely damaged and had to be rebuilt after the slips had been cleared.

The second type of damage occurred where the track was laid on embankments - these subsided or slipped away leaving the trace suspended.

Thirdly the track was pushed out of line for practically the whole 60 mile length of the main effected area.

+ Resident Engineer, N.Z. Railways, Greymouth. 


\section{Restoration force}

Once it was established that the task of restoration was beyond local resources there was a rapid build up of men, plant and material - the volunteers coming from other parts of the West Coast and Canterbury.

At the peak of the restoration there were 180 men excluding plant operators on the site, engaged on track and bridge repairs, Others were involved on restoration of communications.

Earthmoving plant was brought into the area and when the restoration was at full swing there were 20 machines on the site besides sundry trucks. The plant were responsible for clearing 30,000 cu. yds of slip material and providing $19,000 \mathrm{cu}$. yds of filling for rebuilding the formation.

Ballast was required for practically the whole $60 \mathrm{mile}$ length and to augment the ballast from Westport, which in any case was not available to the railhead moving north from Reefton, a contract was negotiated for a supply at Reefton and later at Inangahua. In all, 42,000 cu. yds of ballast was used. One difficulty was in discharging such a large quantity of ballast in minimum time with the local supply of ballast wagons, but this was soon overcome by bringing 2 ballast trains from Canterbury and one from Otago. These remained at Reefton for the duration of the emergency.

The restoration team moving South from Westport were dependant on rail access. They travelled to work on work trains. Work trains also carried supplies, earthmoving plant and ballast. In al1 265 work trains were used during the emergency.

\section{Accommodation}

The volunteers streaming into assist with the restoration overtaxed the accommodation at Reefton. In the camp which consisted of 2 breakdown trains witr sleeping cars and sundry huts, 75 men were accommodated. Meals were provided by 6 cooks and they cooked daily for about 110 workers.

\section{Lessons to be learnt}

The earthquake showed up the weaknesses in the design standards and construction practices of the past. A more detailed analysis of this has been submitted as a technical paper by the author.

\section{Acknowledgement}

The writer thanks the Chief Civil Engineer of the Railways Department for permission to publish this paper. 


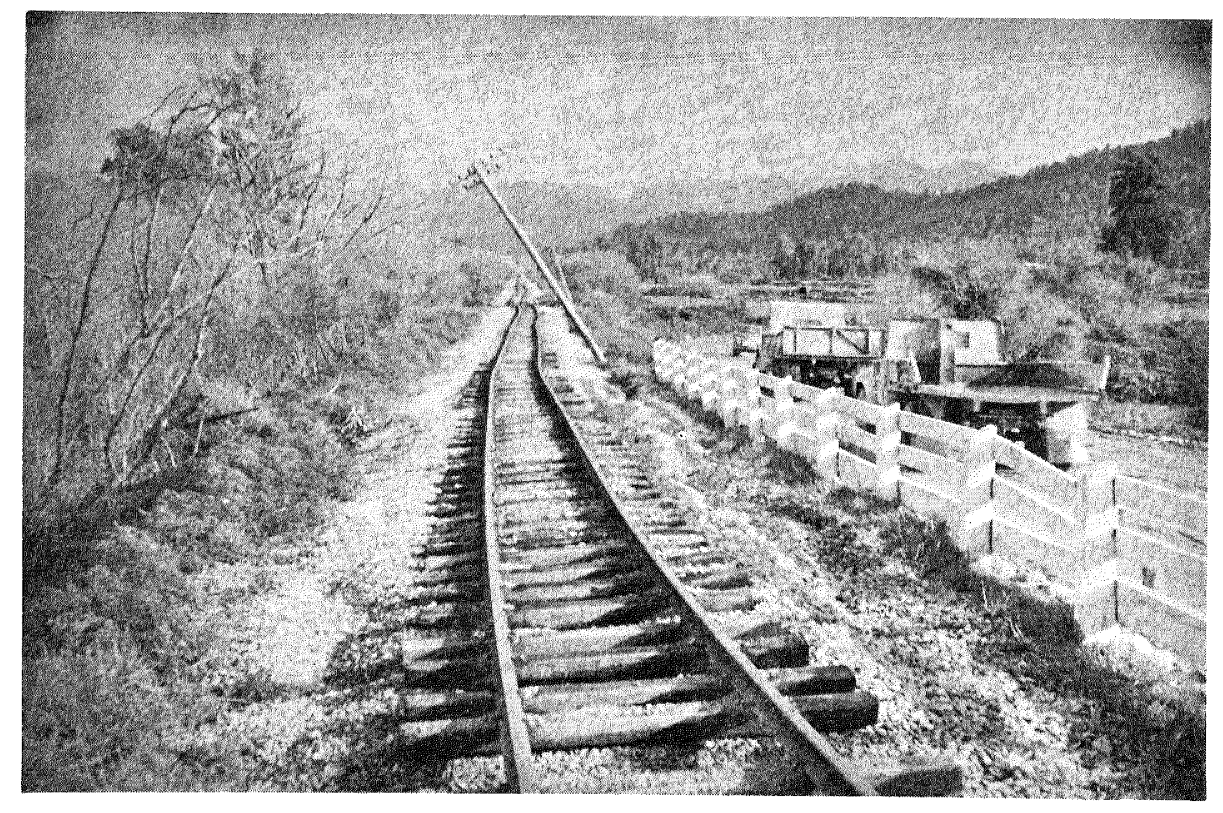

Fig. 1. Track out of line at Inangahua

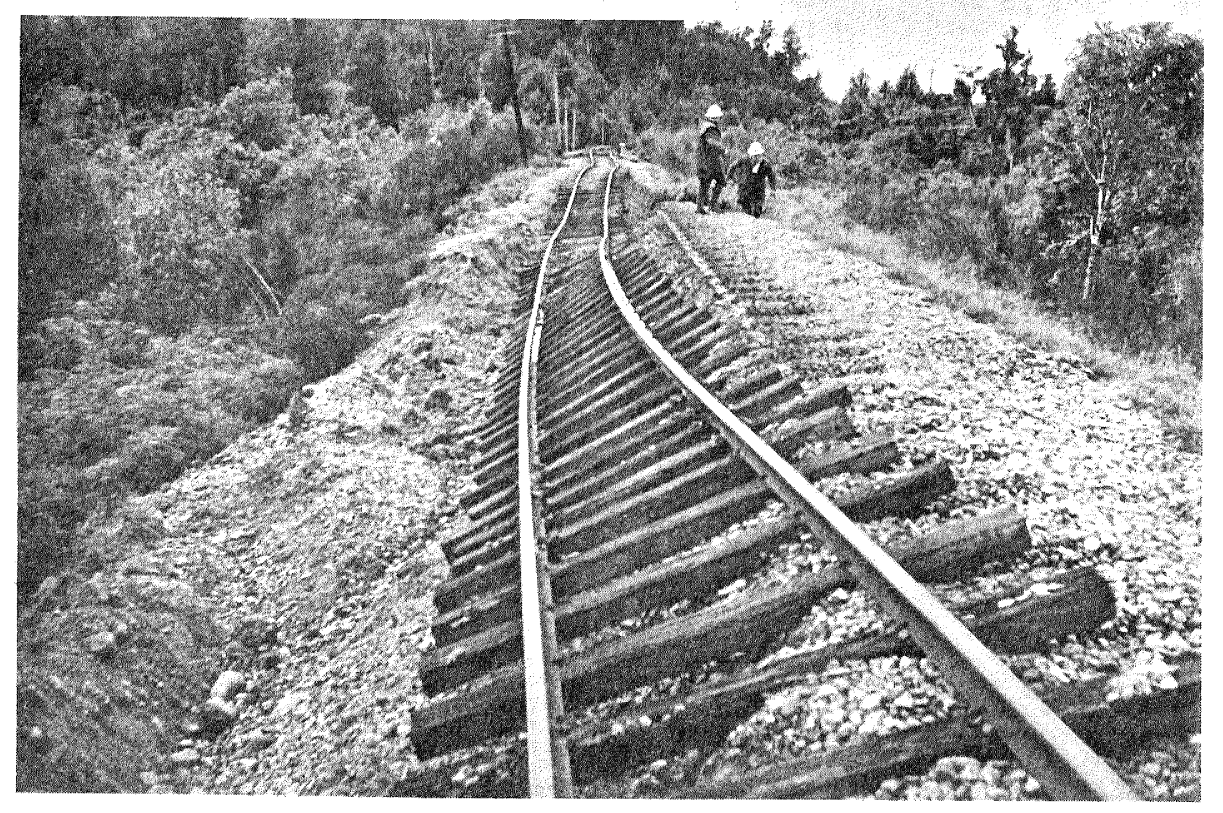

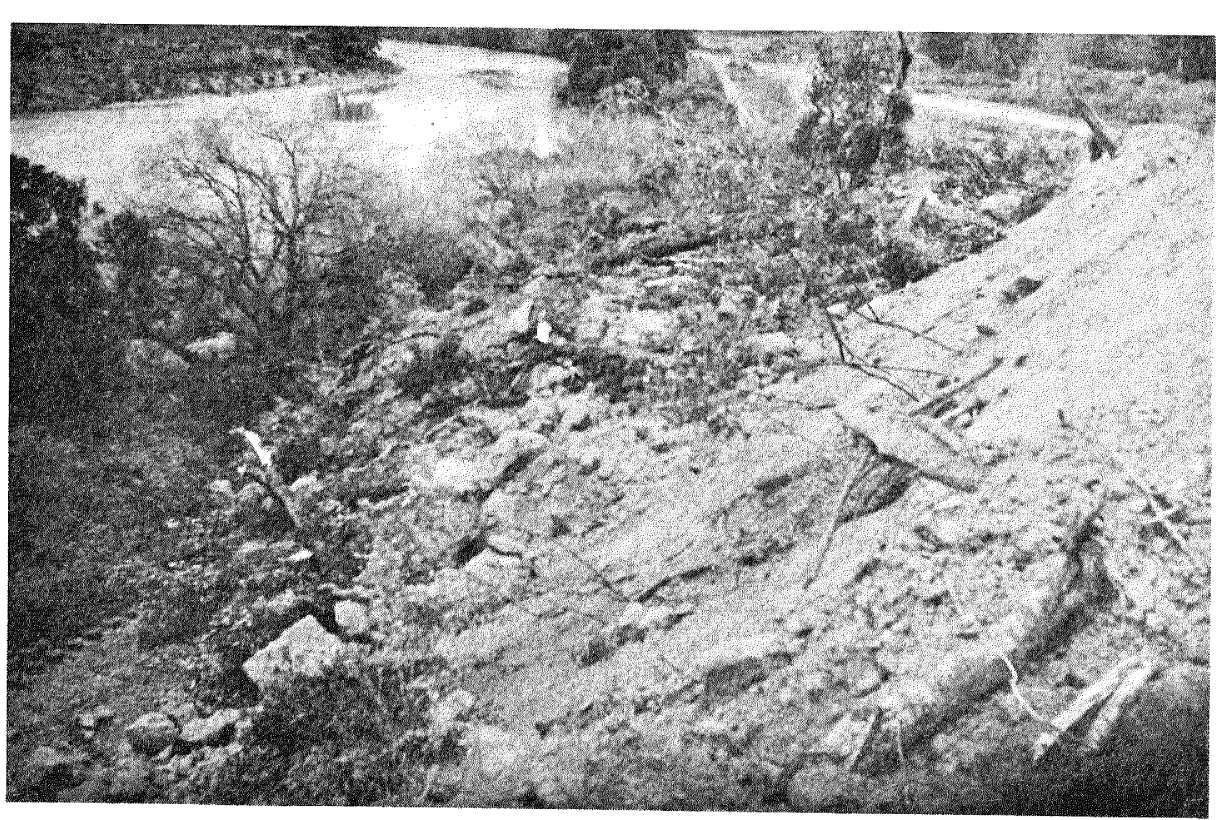

Fig. 3. Slip near Oweka

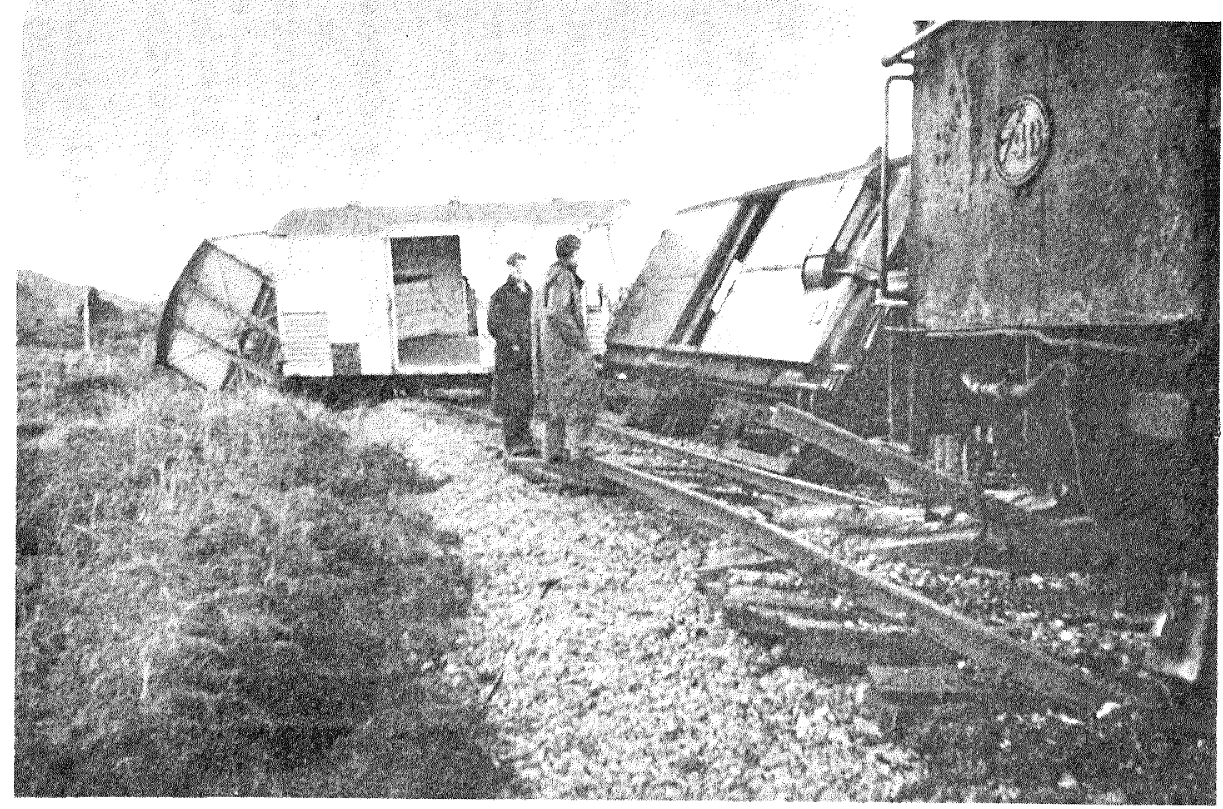

Fig. 4. Moving train derailed near Rotokohu 